\title{
Yaşam tarzı göçü bağlamında kentten kırsala kaçış: Yeni köylü turizm girişimcileri üzerine nitel bir araştırma*
}

\section{In the context of lifestyle migration escape from urban to rural: A qualitative research on new villager tourism entrepreneurs}

Gönderim Tarihi / Received: 05.11.2021

Kabul Tarihi / Accepted: 14.12.2021

doi https://doi.org/10.31795/baunsobed.1019745
Sultan Nazmiye KILIÇ**1 Cemali BUZLUKÇU⿱2

ÖZ: $\mathrm{Bu}$ araştırmada sayıları son yıllarda gittikçe artan yeni köylü turizm girişimcilerinin motivasyonları, göç süreçleri ve girişimlerine yönelik deneyimlerinin açığa çıkarılması amaçlanmıştır. $\mathrm{Bu}$ doğrultuda nitel araştırma yöntemi desenlerinden biri olan fenomenolojik desen kullanılmıştır. Yeni bir yaşam biçimi için kentten kırsala göç eden yeni köylü turizm girişimcilerinin yaşadıkları deneyimlerin anlaşılabilmesi için bu kişilerle yapılan röportajları içeren videolar incelenmiş ve elde edilen verilere tematik analiz uygulanmıştır. Ulaşılan bulgular göz önünde bulundurularak, yeni köylü motivasyonları itici ve çekici faktörler altında değerlendirilmiştir. Çekici faktörler altında çevresel unsurların, itici faktörler altında ise psikolojik unsurların ön plana çıktığı tespit edilmiştir. Kırsala göç süreci yeni köylü turizm girișimcileri tarafından doğal yaşama kaçıș olarak nitelendirilmiştir. Bu kaçışın farklı sebepleri olmakla birlikte, temel olarak altta yatan sebeplerin; modern hayat içindeki kalabalık, betonlaşma, gereksiz tüketim nedeniyle daha fazla çalışma gibi sorunlar olduğu anlaşılmıştır. Ancak, şehirden kırsala yapılan göçlerle birlikte yeni köylülerin tarafından da vurguladığ 1 gibi şehir yaşamının alışkanlıklarının kırsal alanlara taşınması ve bu göç hareketlerinin kitlesel bir duruma dönüşmesi gibi tehditlerin göz önünde bulundurulması gerekmektedir.

Anahtar Kelimeler: Yeni köylüler, Turizm girişimciliği, Yaşam tarzı göçü, Kırsal turizm

ABSTRACT: In this research, it is aimed to reveal the motivations, migration processes and entrepreneurship experiences of new villager tourism entrepreneurs, whose number has been increasing in recent years. In this direction, the phenomenological design, which is one of the qualitative research method designs, was used. In order to understand the experiences of new villager tourism entrepreneurs who migrated from the urban to the rural for a new lifestyle, the videos containing the interviews with these people were examined and thematic analysis was applied to the obtained data. Considering the findings, new villager motivations were evaluated under push and pull factors. It has been determined that environmental factors come to the fore under pull factors and psychological factors come to the fore under push factors. The process of migration to the countryside has been described as an escape to the natural life by new villager tourism entrepreneurs. Although there are different reasons for this escape, basically the underlying reasons are problems such as crowding, concretion in modern life, excessive workload due to unnecessary consumption. However, as emphasized by the new villagers along with the migration from the city to the countryside, the threats such as the transfer of the habits of city life to the rural areas and the transformation of these migration movements into a mass movement should be taken into consideration.

Keywords: New villagers, Tourism entrepreneurship, Lifestyle migration, Rural tourism

\footnotetext{
${ }^{*}$ Bu çalışma, 21.Ulusal / 5.Uluslararası Turizm Kongresi’nde sunulan tam metin bildirinin genişletilmiş halidir.

** Sorumlu Yazar / Corresponding Author

${ }^{1}$ Arş. Gör. Dr., Balıkesir Üniversitesi/Turizm Fakültesi/Turizm İşletmeciliği Bölümü, sultan.kilic@ balikesir.edu.tr,

(D) https://orcid.org/0000-0003-0560-0622

2 Arş. Gör. Dr., Balıkesir Üniversitesi/Turizm Fakültesi/Turizm İşletmeciliği Bölümü, cemalibuzlukcu@ balikesir.edu.tr,

(D) https://orcid.org/0000-0001-6207-5735
} 


\section{EXTENDED ABSTRACT}

\section{Literature review}

The rapid leaps in migration from rural to urban areas have brought along some economic and social problems in urban life (Güreşci, 2010: 77-79; Bostan, 2017). Problems such as the inability of immigrants to keep up with the urbanization process, the inability of industrialization to develop in parallel with migration rates, and therefore the increase in unemployment in cities, and squatting can be given as examples (İslamoğlu, Yıldırımalp, \& Benli, 2014: 72-73). At this point, it can be said that cities have lost their pull factors and push factors have emerged (İçli, 1998; Güreşci \& Yurttaş, 2008; Güressci, 2010). As the economic and socio-cultural expectations of the immigrants who migrated from the village to the city cannot be met, it is seen that reverse migration has taken place in Turkey, especially in the 2000s, and the reverse migration phenomenon has gained importance (Gümüş, İlhan, \& Gülersoy, 2013; İslamoğlu, Yıldırımalp, \& Man, 2017). Reverse migration means that a sending country, city, or region begins to receive migrants (Chacko, 2007: 132; İslamoğlu et al., 2014: 69). In particular, the necessity of working more to meet the hedonic consumption in urban areas has made the originality and quality of this life questioned (Baş̧̧1, 2019: 3). In addition, reasons such as rapid urbanization and overcrowding have caused people to move to rural areas (Eimermann, 2015: 68). In recent years, Covid-19 has been one of the factors that triggered migration to rural areas and there has been an increase in interest towards secondary housing in rural areas (Zoğal \& Emekli, 2020; Sürer, 2021: 1). These people who migrated from urban areas to rural areas are referred as "new villagers" (Savgin \& Zengin, 2018: 255). Along with the migration from the city to the rural areas, the educational and experiential knowledge gained in urban life is transferred to the rural life. In this context, the lifestyles of the peasantized city dwellers can be described as "hybrid lives". Therefore, the 'sociology of the peasantized city dwellers' has become a new field of study (Başş1, 2019: 17). What motivations are underneath the radical change in the lifestyles of these people who migrate from the city to the countryside and make initiatives in the field of tourism constitute the problem of the research. In this context, it is aimed to reveal the motivations, migration processes and experiences of new villagers who are tourism entrepreneurs.

\section{Methodology}

In line with the problem and purpose of the research, the data on the motivations, migration processes and initiatives of new villagers were evaluated using the phenomenological design, which is one of the qualitative research method designs. Accordingly, all interview videos which can be accessed through YouTube video sharing platform, carried out with participants migrated from city to countryside and undertook tourism activities were evaluated. The information in the video content was coded in line with the predetermined themes and a total of 240 codes were assigned. New themes and categories have been identified where necessary. Subcodes, codes, categories and themes were determined by the consensus of researchers and thematic analysis was applied by coding the relevant video segments in the MAXQDA program. 6 videos were examined, and it was determined that the relevant initiatives were in the provinces of İzmir, Rize and Muğla. The staying duration of new villagers in the countryside varies between 6 months and 20 years. Their professions are entrepreneur, tradesman, public servant, tourism professional and private sector employee. It has been determined that the tourism activities carried out by the new villagers after the migration are in the fields of rural tourism, camp/caravan, and hostel management.

\section{Findings and discussion}

According to the information obtained from the videos, it was decided to separate the motivational factors as push and pull factors. Pull factors were examined under 5 sub-categories: Cultural, social, psychological, environmental, and personal. Push factors were analyzed under 5 sub-categories: economic, cultural, social, psychological, and environmental. In line with the findings, it was understood that the new villagers wanted to live without breaking away from traditional production, trying to revive the forgotten culture. It is also found out that in rural life, in addition to collective work, the presence of more intimate and social relations with respect to city life are pull social factors. The freedom that nature provides to people, the feeling of pleasure, and the advantages of living away from stress are among the psychological factors. However, elements such as the silence, peace, 
stepping into the ground, and nature scenery of rural areas were included under environmental factors. Finally, it has been observed that familiarity with the place of migration, interest in caravans, desire to live by producing and simplification are under the personal factors grouped in line with the interests and wishes of the individuals.

The first sub-category evaluated under push factors is economic factors. Accordingly, individuals want to get away from intensive working life and labor exploitation in modern life. Under cultural factors, cultural erosion, reaction to mass tourism and popular culture has been determined. Escape from crowds and unhappy people has been observed under social factors. It has been understood that the psychological factors that push individuals away from city life are stress, problem of belonging, saturation with modern life, fear of terrorism and the desire to experience a different life. Finally, it has been determined that environmental factors are reaction to excessive consumption, desire to support sustainable life, escape from concretion, traffic jams, and individuals' inability to feel nature.

It can be said that the new villagers are people who care about nature, are against excessive consumption, see humanity as a part of nature, desire to get away from the habits of modern life, and are connected to culture. It has been understood that the new villagers have gained in nature, social relations and wellness, and they have faced various difficulties brought by the new lifestyle. Finally, it was emphasized that individuals who want to change their lifestyle should adapt to nature and act consciously.

\section{Results and recommendations}

In this study, it is aimed to reveal the experiences of new villager tourism entrepreneurs about their motivations, migration processes and initiatives. Considering the findings, it can be said that the new villagers are such individuals that position nature at the center of their lives and oppose the excessive consumption habits imposed by popular culture. In addition, it can be stated that the new villagers desire to continue the production and lifestyle existing in traditional village life, do not adapt to modern life, but use technology effectively. In this respect, it is seen that the hybrid lifestyle described by Başç (2019) for new villagers is also supported in this study. It is thought that the new villagers prefer tourism entrepreneurship as a tool to maintain the lifestyle that positions the nature at the center of their lives. Thus, it can be argued that their primary motivation for the migration is not tourism entrepreneurship or economic benefits, but a natural and sustainable way of life. One of the important findings of the study is that environmental factors stand out among pull motivational factors and psychological factors come to the fore among the push motivation factors. While pull environmental factors often emphasize calmness and serenity with the advantages that nature offers to people, the push psychological factors consist of elements related to the incompatibility of the individual with modern life.

The process of migration to the countryside has been described as an escape to the natural life by new villager tourism entrepreneurs. Although there are different reasons for this escape, basically the underlying reasons are problems such as crowding, concretion in modern life, excessive workload due to unnecessary consumption. As a matter of fact, similar reasons were highlighted by Eimermann (2015) and Başçı (2019).

Especially due to epidemics such as Covid-19, it is predicted that escapes from the city will increase (Zoğal \& Emekli, 2020; Sürer, 2021). Accordingly, it can be argued that the number of new villager tourism entrepreneurship will be affected in the near future. However, as emphasized by the new villagers within the scope of the research, the transfer of urban life habits to rural life and the transformation of this migration into a mass movement may pose a threat that should be considered. In future studies, the local people's view of the new villagers can be evaluated. In addition, the threats and opportunities perceived by the local people from these migration movements can be examined and the motivation factors obtained as a result of the research can be tested on larger sample groups. 


\section{Giriş}

Kırsaldan kente akın eden göçlerde yaşanan hızlı artışlar kentsel yaşam içerisinde baş gösteren birtakım ekonomik ve sosyal problemleri de beraberinde getirmiştir (Güreşci, 2010: 77-79; Bostan, 2017). Göç eden bireylerin kentleşme sürecine ayak uyduramaması, sanayileşmenin göç hızlarına paralel olarak gelişememesi ve bundan dolayı kentlerde işsizliğin artması, gecekondulaşma gibi sorunlar bunlara örnek gösterilebilir (İslamoğlu, Yıldırımalp ve Benli, 2014: 72-73). Bu noktada kentlerin artık çekici faktörlerini yitirdiği ve itici faktörlerle dolmaya başladığı söylenebilir (İçli, 1998; Güreşci ve Yurttaş, 2008; Güreşci, 2010). Köyden kente göç eden göçmenlerin kent hayatından elde etmek istedikleri ekonomik ve sosyo-kültürel beklentilerin karşılanamaması ile birlikte, özellikle 2000'li yıllarda, Türkiye'de tersine göçlerin yaşandığ1 ve tersine göç olgusunun önem kazandığ1 görülmektedir (Gümüş, İlhan ve Gülersoy, 2013; İslamoğlu, Yıldırımalp ve Man, 2017). Tersine göç, insanların göç ederek ayrıldığı şehirlerin, bölgelerin veya ülkelerin göç almaya başlaması olarak tanımlanmaktadır (Chacko, 2007: 132; İslamoğlu vd., 2014: 69). Özellikle, kentsel alanlarda hazsal tüketimin parasal olarak karşılanabilmesi için daha fazla çalışma gerekliliği, yaşanan bu hayatın özgünlüğünü ve niteliğini sorgulatır hale getirmiştir (Başçı, 2019: 3). Bunun yanı sıra, hızlı kentleşme ve aşırı kalabalık gibi sebepler, kişilerin kırsal alanlara taşınmasına neden olmuştur (Eimermann, 2015: 68). Son y1llarda ise Covid-19 kırsal alanlara gerçekleştirilen göçü tetikleyen faktörlerden biri olmuştur ve kırsal alanlarda bulunan ikincil konutlara yönelik ilgide artış görülmüsstür (Zoğal ve Emekli, 2020; Sürer, 2021:1). Kentsel alanlardan kırsal alanlara göç eden bu kişiler "yeni köylüler" olarak ifade edilmektedir (Savgın ve Zengin, 2018: 255). Yeni köylüler kimi zaman bölgenin yok olmaya yüz tutmuş değerlerini yeniden canlandırabilmektedir. Örneğin, Cevennes bölgesinin "pélardon" peyniri, yeni köylüler tarafından yeniden gözden geçirilmiştir (Bérard, Marchenay ve Casabianca, 2010: 155).Yeni bir tüketici profili sergileyen yeni köylülerin "doğaya ve insana karşı sorumluluk ve saygı duyan, tüketim bilinci yüksek, istek ve arzuları ekseninde haz ilkesiyle değil sınırlı ve sade bir yaşamı benimseyen, geçmiş yaşam bilgilerini edinerek onu yaşatmaya çalışan, kendi ürününü üreterek kendi kendine yeten bir düzen yaratan, huzur ve mutluluğu çok mala sahip olmadan sade ve derin yaşamda, dayanışma ve paylaşma kültüründe bulan özellikler sergilediği" ifade edilmektedir (Özdemir, 2020: 846).

Kentten kırsal alanlara yapılan göçlerle birlikte, kent yaşamında edinilen eğitimsel ve deneyimsel birikimler köy yaşamına aktarılmaktadır. Bu kapsamda, köylüleşen şehirlilerin hayat tarzı "melez hayatlar" olarak nitelendirilmiş ve 'köylüleşen şehirlilerin sosyolojisi' yeni bir çalışma alanı haline gelmiştir (Başçı, 2019: 17). Kentten kırsala göç ederek turizm alanında da girişimlerde bulunan bu kişilerin yaşam biçimlerine ilişkin radikal değişim kararı almalarının altında ne gibi motivasyonlar olduğu araştırmanın problemini oluşturmaktadır. Bu bağlamda turizm girişimcisi olan yeni köylülerin motivasyonları, göç süreçleri ve girişimlerine dair deneyimlerinin ortaya çıkarılması amaçlanmıştır.

\section{Literatür taraması \\ Göç}

Göç; bireylerin, doğal, ekonomik, toplumsal ve siyasi birtakım faktörler nedeniyle coğrafi boyutta yer değiştirmesi olarak tanımlanmaktadır (Adıgüzel, 2016: 3). Bu yer değiştirme kimi zaman bireyin yaşadığı ülke sınırları içerisinde kimi zaman ise uluslararası boyutta gerçekleşebilir. Göç kavramının tanımında, genel olarak ikamet edilen yerin, kalıcı veya yarı kalıcı bir biçimde değişikliği vurgulanmaktadır. Buna göre; gönüllü veya zorunlu, sürekli veya geçici, iç veya dış, düzenli veya düzensiz, bireysel veya kitlesel her türlü hareket göç kavramı içerisinde yerini almaktadır (Lee, 1966: 49). İnsanlık tarihinin neredeyse her aşamasında karşımıza çıkan göç (Güvenç, 1999: 122), bireyin psikolojik durumu üzerinde yarattı̆̆ 1 etkiler ile birlikte; sosyal, siyasal, ekonomik, çevresel ve mekânsal etkiler de yaratabilmektedir (Y1lmaz, 2014; Ekici ve Tuncel, 2015). Bu nedenle, toplumsal yaşamı bu derecede yakından etkileyen göç olgusunu anlamaya ve bireylerin veya grupların göç etmelerinin altında yatan sebepleri açıklamaya yönelik çeşitli kuramlar ileri sürülmüş̧ür (Çağlayan, 2006). Bu kuramlara; Ravenstein'ın Göç Kanunları (Ravenstein, 1885) ve Lee'nin İtme ve Çekme Kuramı (Lee, 1966) çalışmalarının öncülük ettiği söylenebilir. Göçle ilgili ilk çalışmalardan biri olarak kabul edilen Ravenstein'ın çalı̧̧ması, göç olgusuna ilişkin yedi kanunu ortaya koymaktadır. Buna göre, göç konusunda genel geçer birtakım kanunlar vardır ve göç bu kanunlara göre gerçekleşmektedir. Göç edenlerin çoğunun yakın mesafelere göç etmesi, uzun mesafelerdeki göçlerin 
genellikle ticaret merkezlerine veya büyük şehirler merkezlerine doğru olduğu ve kırsal bölgelerde yaşayan bireylerin göç etme eğiliminin kentlerde yaşayanlardan fazla olması bu kanunlara örnek olarak gösterilebilir. Lee ise, Bir Göç Teorisi adlı çalışmasında, ikamet edilen yer ile varılacak yere ilişkin pozitif ve negatif unsurların göçün belirleyicileri olduğunu ifade etmiştir (Özcan, 2017: 189191).

Göç olgusunun dinamik yapısı ve kendini yenilemesi sebebiyle, göç hareketlerini açıklamaya yönelik ileri sürülen kuramların zaman içerisinde kapsayıcılığını yitirdiği belirtilmektedir (Çağlayan, 2006: 89). Bundan dolayı, günümüzde göç, yukarıda tanımlanan göç tanımları ile sınırlı kalmamıştır. İç göç sürecine yeni bir bakış kazandıran ve nispeten daha güncel bir kavram olan "yaşam tarzı göçü" bu çerçevede değerlendirilmektedir. Benson ve O'Reilly (2009b) tarafindan ileri sürülen yaşam tarzı göçü (lifestyle migration) kavramı, genellikle büyük şehirlerde yaşayan ve belirli bir ekonomik gelir düzeyine sahip her yaştan bireyin, birçok sebeple, geçici veya kalıcı şekilde daha iyi bir yaşam tarzına ulaşacaklarına inandıkları yerlere yönelik gerçekleştirdikleri göç hareketleri olarak tanımlanmaktadır. Her bir göç olayı kendine has özelliklere sahip olmasına rağmen, araştırmacılar, yaşam tarzı göçünü; emeklilik göçü, boş zaman göçü, karşı kentleşme, ikinci konut sahipliği, refah göçü ve mevsimlik göç gibi kavramları kapsayan bir şemsiye kavram olarak kullanmış ve böylece daha geniş fenomenlerle ilişkilendirmeye çalışmışlardır (Benson ve O'Reilly, 2009b: 609). Bu kapsamda, yaşam tarzı göçü, bireylerin daha iyi bir yaşam sürecekleri beklentisi ile göç hareketinde bulunmaları olarak tanımlanmaktadır (Südaş ve Mutluer, 2010: 31). Ülkeler arası ve bir ülke içinde gerçekleşen göçlerin etkileri ve sebepleri birbirinden farklı olabilmektedir (Sayın, Usanmaz ve Aslangiri, 2016; Bostan, 2017). Ülke içinde gerçekleşen ve iç göç olarak adlandırılan göçler; genellikle köy ve kasaba gibi kırsal alanlarla ilçe ve şehir merkezi gibi kentsel mekanlar arasında gerçekleşmektedir. Bununla birlikte, iç göç sonucunda ülke nüfusunda herhangi bir değişim yaşanmamaktadır. İç göçlerin sebepleri arasında; tarıma ve hayvancılığa dayalı problemler, terör ve benzeri siyasal nedenler, kırsal bölgelerdeki sosyal yapıdan uzaklaşma isteği, kentlerin sağladığı sosyal ve kültürel imkanlardan yararlanma arzusu, kentlerde iş olanaklarının fazla olduğu düşüncesi bulunmaktadır (Şen, 2014).

Türkiye'de iç göçlerin 1950'li yıllardan itibaren değişen oranlarda yaşandığı görülmektedir. Özellikle 1980 yılı sonrasında daha da hızlanan iç göçlerin genellikle kırsal bölgelerden kentlere doğru; ekonomik, toplumsal ve siyasal nedenlerle meydana geldiği söylenebilir (Bülbül ve Köse, 2010; İslamoğlu, Yıldırımalp ve Benli, 2014). Türkiye'de yıllara göre kent ve köy yerleşimlerinin nüfus dağılımları incelendiğinde; 1980 yılına kadar köy nüfusunun kent nüfusuna oranla daha fazla olduğu, 2000'li yıllarla birlikte köy nüfusundaki azalışın devam ettiği ve 2019 y1lına gelindiğinde ülke nüfusu içerisinde köy nüfusu oranının \%7,2'ye düştüğü, kent nüfusunun ise \%92,8'e yükseldiği görülmektedir (TUIK, 2020). Bununla birlikte, 1945 - 1990 yılları arasında yaşanan kentsel büyümenin \%52'sinin köyden kente göçler sonucunda oluştuğu, doğal artışın ise kentsel büyümede \%30 oranında etkili olduğu belirtilmektedir (İçduygu, Sirkeci ve Aydıngün, 1998: 219).

\section{Turizm girişimciliği ve göç}

Kentten kırsal alanlara yapılan göçlerin artmasında giriş bölümünde bahsi geçen nedenlerle birlikte kurum ve kuruluşların tarım ve hayvancılık alanında sağlamış olduğu destekler de önemli birer unsurdur. Kırsal bölgelerin kalkınması amacıyla yürütülen proje ve faaliyetler doğrultusunda girişimcilere verilen hibe ve kredi imkanları göçmenlerin köylerine dönüp tarım ve hayvanc1lıkla ilgilenmelerini ve bu sektörlerin yeniden canlanmasına da katkı sağlamıştır (İslamoğlu vd., 2014: 72; Akkaya ve Gülçubuk, 2019). Bu tip destekler turizm sektörü için de sağlanmaktadır. Bu nedenle, kırsal alanlara yapılan göçlerde turizm girişimciliği faaliyetlerinin incelenmesi de faydalı olabilir.

Girişimcilik, risk ve belirsizlik şartları altında kazanç veya büyüme amacıyla yenilikçi ekonomik kuruluşların oluşturulmasıdır (Dollinger, 2008: 28). Girişimcilerin en önemli özelliklerinden biri hali hazırda var olan kaynakları daha önce yapılmamış formlarda bir araya getirmesidir (Schumpeter, 2000). Kırsal turizm girişimciliğinin gelişiminde farklı unsurların rolü bulunmaktadır. Bunlar; tarımın azalması, nüfusun dış göçü ve sürdürülebilir turizm türlerine olan talebin artmasıdır (Lordkipanidze, Brezet ve Backman, 2005: 797). Savgın ve Zengin'in (2018: 239) araştırmasına göre çiftlik turizmi, yoğun olarak kırsala göç eden kişiler tarafindan gerçekleştirilmektedir. Bu kişiler, şehirden uzaklaşma 
ve kırsal alanlarda yaşamaya "özlem" duyan insanlar için "rol model" olarak görülmektedir. Kendi kendine yetme ve üretimin doğal olması gibi değerlere sahip çıkılmaktadır. Ayrıca bu kişiler, kırsal alanlara yerleşmeyi düşünen kişilere kolaylık sağlayabilmektedir. Ancak, verilen kamu desteklerinin formalitelerinin kolaylaştırılması gerektiği düşünülmektedir (Savgın ve Zengin, 2018: 239). Swan ve Morgan (2016: 120) tarafından gerçekleştirilen araştırmada ise eko-girişimcilerin ekolojik değerlere uygun ve bilinçli olarak az etkili eko turizm işletme faaliyetleri yürüttükleri sonucuna ulaşılmıştır. Ayrıca, eko-girişimciler kontrolsüz gelişmenin ve hassas doğal alanların kitle turizmine açılmasının neden olacağ 1 tehditlere ilişkin tahminlerde bulunmuştur. Bir başka deyişle, küçük eko turizm işletmelerinde, girişimcilerin işletme hedefleri, yaşam tarzına yönelik amaçları ve sürdürülebilir çevresel uygulamalarla ilgili konularda dengeyi sağlamaları gerekmektedir. Bu nedenle, sürdürülebilir turizm girişimciliğinin arttırılabilmesi için girişimcilik kültürü ve ikliminin anlaşılması önemli bir ön koşul olarak görülmektedir. Ayrıca, mali destek, eğitim, tanıtım ve mentorlük konuları da girişimcilerin motive edilmesi bakımından önemlidir (Lordkipanidze vd., 2005: 798).

\section{Yeni köylüler}

Yeni köylüler, yaşam tarzı göçü ve yaşam tarzı girişimciliği kapsamında incelenebilmektedir. Yaşam tarzı göçü, kendini gerçekleştirme ve keşfetme, arzularının peşinden gitme ve bireyin potansiyelini açığa çıkaracak yeni bir hayat kurmak amacıyla bir yerden veya bir şeylerden kaçışı ifade etmektedir (Benson ve O'Reilly, 2009a: 2). Yaşam tarzı girişimciliği ise, genellikle küçük işletme girişimciliği ile karakterize edilmektedir. Bu girişimde bulunan kişiler "sahip-yönetici" olarak çalışmakta, girişimlerini kendi değerleri ve sosyo-politik ideolojileri temelinde gerçekleştirmektedir (Ateljevic ve Doorne, 2000). Yaşam tarzı girişimcilerinin motivasyon unsurları da diğer girişimcilere göre farklılık göstermektedir. Bu girişimciler ekonomik kazanç elde etmekten çok yaşam kalitesini dikkate almakta, ailesi ile daha fazla vakit geçirmeye önem vermekte, kişisel istek ve ihtiyaçlarını ön plana çıkarmaktadır (Aslan, 2019). Her iki kavramın özelliklerini bünyesinde barındıran yeni köylüler, genellikle şehir hayatının getirdiği zorluklardan kaçıp kırsal bir alana yerleşen ve burada kendi değerleri ve yaşam anlayışlarını destekleyen bir yaşam tarzını sürdürebilmek amacıyla girişimde bulunan kişileri tanımlamaktadır. Bu kişilerin ekonomik, toplumsal ve çevresel değer ve kaygıları ile şehir hayatının sunduğu yaşam biçiminin uyuşmadığı görülmektedir (Sun ve Xu, 2017). Yeni köylü kavramı bu çalışmada çeşitli kaygılar ve beklentiler doğrultusunda yaşam tarzı göçü ve girişimciliği gerçekleştiren kişileri tanımlamak amacıyla kullanılmıştır. Turizm sektörü ile yaşam tarzı göçü ve girişimciliği arasında yakın bir ilişki bulunmaktadır. Turizm girişimciliğinde iş ve aile hayatını kombine etme şansı bulunmakta, hobi ve özel ilgilerin geliştirilmesi desteklenebilmekte, girişimcilerin kendi işinin patronu olma imkânı bulunmakta, özerklik ve bireysellik de beraberinde gelmektedir (Wilson, 2007: 359). Bu araştırmada, turizm sektörü ile vurgulanmak istenen kitle turizmi ve kitlesel faaliyetlere imkân sunan girişimler değil, daha çok kırsal kesimde kurulan kamp-karavan, agro-turizm, çiftlik turizmi, ekolojik köy ve butik otel gibi küçük ölçekli işletmeler ve benzeri diğer girişimlerdir.

Bu araştırmada şehirden kırsala yeni bir yaşam tarzı kurmak amacıyla göç etmiş yeni köylü turizm girişimcilerinin motivasyonları incelenmiştir. İlgili alanyazın göz önüne alındığında yeni köylülerin turizm girişimciliği motivasyonlarının ve deneyimlerinin anlaşılmasına yönelik yeterli çalışmaya ulaşılamamıştır. Bu kapsamda, araştırmanın ilgili alanyazına katkı sağlaması ve var olan uygulamaları değerlendirmesi bakımından faydalı olacağı düşünülmektedir.

\section{Yöntem}

Kentten kırsala göç ederek turizm alanında girişimlerde bulunan yeni köylülerin yaşam biçimlerine ilişkin radikal değişim kararı almalarının altında ne gibi motivasyonlar olduğu araştırmanın problemini oluşturmaktadır. Bu kapsamda araştırmada cevap aranan sorular şunlardır: Yeni köylü turizm girişimcilerinin göç motivasyonları nelerdir? Yeni köylü turizm girişimcilerinin karakteristik özellikleri nelerdir? Yeni köylü turizm girişimcilerinin göç sonrası kazanımları, karşılaştıkları zorluklar ve tavsiyeleri nelerdir? Araştırmanın problemi ve amacı doğrultusunda; nitel araştırma yöntemi desenlerinden biri olan fenomenolojik desen kullanılarak yeni köylülerin motivasyonlarına, göç süreçlerine ve girişimlerine yönelik veriler değerlendirmeye alınmıştır. Nitel araştırmalarda insanların hayatı anlamlandırmaları, deneyimleri ve algılarıyla ilgilenilmektedir (Merriam, 2013: 13). Fenomenoloji deseni ise derinlemesine ve detaylı bilgimizin bulunmadığı, açıklamak ve betimlemek 
istediğimiz olgulara odaklanmaktadır. Fenomenoloji araştırmalarında, yaşantıları ve anlamları keşfetmek amacıyla veri analizi gerçekleştirilmektedir (Yıldırım ve Şimşek, 2016: 69-72). Bu kapsamda, seçilen yöntemin ve desenin yeni köylü turizm girişimcilerinin deneyimlerinin anlaşılması için uygun olacağına karar verilmiştir. Videolar YouTube video paylaşım platformu üzerinde "yeni köylü", "kentten kırsala göç", "kırsala kaçış", "kırsalda yeni bir hayat" ve "şehirden kaçanlar" gibi anahtar kelimeler kullanılarak taratılmış ve konu ile ilişkili videoların tamamı araştırmaya dâhil edilmiştir. Araştırmanın katılımcılardan veri toplanmasını gerektirmemesi sebebi ile etik kurul izni gerektirmeyen çalışmalar arasında yer aldığı belirlenmiştir. Video içerik sitesinde gerçekleştirilen aramalarda araştırma konusuna benzer içeriklerin yoğunluk gösterdiği belirli kanallar olduğu anlaşılmış ve bu kanalların içerikleri detaylıca incelenmiştir. Bundan dolayı elde edilen veriler video içerik sitesine yüklenen ve şehirden kırsala göç etmiş turizm girişimcilerinin deneyimleri ve tecrübelerini aktardıkları videolar ile sınırlıdır. Bu çerçevede konu ile alakalı yalnızca 6 video değerlendirmeye alınabilmiştir. Ulaşılan videolar TRT Belgesel, 360 Doğal Yaşam ve +90 YouTube kanallarından elde edilmiştir. Benzer bir inceleme Özdemir'in (2020) çalışmasında da kullanılmıştır. Videoların süresi en az 11.18" ve en fazla 34.16" aralığındadır. Video içeriğinde yer alan bilgiler önceden belirlenen temalar doğrultusunda kodlanmış ve toplamda 240 kod oluşturulmuştur. Gerekli görülen durumlarda yeni temalar ve kategoriler belirlenmiştir. Alt kodlar, kodlar, kategoriler ve temalar araştırmacılar tarafından üzerinde uzlaşılarak belirlenmiş ve MAXQDA programında ilgili video kesitlerine kodlama yapılarak tematik analiz uygulanmıştır. Tematik analiz kullanışlı ve esnek bir yöntemdir. Ayrıca, verilerin toplumsal ve psikolojik boyutta yorumlanabilmesine imkân tanımaktadır (Braun ve Clarke, 2006: 77-97). Araştırmada kodların oluşturulmasında faydalanılan temel kaynak incelenen videolar olmuştur. Kodlamalar göz önünde bulundurularak kategoriler ortaya çıkarılmış ve temalar altına dâhil edilmiştir. Başlangıç temaları ise araştırma soruları doğrultusunda oluşturulmuştur. Yeni köylü göç motivasyonlarında Lee'nin İtme ve Çekme Kuramı'ndan (Lee, 1966) yola çıkılarak itici ve çekici faktörlere ilişkin iki kategori oluşturulmuştur. Geçerlik ve güvenirliğin desteklenmesi amacıyla; ilgili videolar birden fazla kez izlenmiştir, videolar araştırma amacı göz önünde bulundurularak seçilmiştir, iki araştırmacı tarafindan kodlarda uzlaşma sağlanmıştır ve araştırma süreçleri ayrıntılı betimlenmiş ve ilgili veri kaynakları kaydedilmiştir (Erlandson, Harris, Skipper ve Allen, 1993; Yıldırım ve Şimşek, 2016: 277). Değerlendirilen videolara ve katılımcılara ilişkin veriler Tablo 1'de sunulmuştur. Buna göre, toplamda 6 video incelenmiş ve ilgili girişimlerin İzmir, Rize ve Muğla illerinde olduğu tespit edilmiştir. Yeni köylülerin kırsalda yaşama süresi 6 ay ve 20 yıl arasında değişmektedir. Daha önceki meslekleri incelendiğinde girişimci, esnaf, kamu görevlisi, turizmci ve özel sektör çalışanı oldukları anlaşılmıştır. Daha önceki ikametlerinin ise İstanbul, İzmir ve Ankara gibi büyük şehirler olduğu görülmüştür. Yeni köylülerin göç sonrası yürüttükleri turizm faaliyetlerinin ise kırsal turizm, kamp/karavan ve pansiyon işletmeciliği alanlarında olduğu tespit edilmiştir.

Tablo 1: Tanımlayıc bilgiler

\begin{tabular}{|c|c|c|c|c|c|c|c|c|}
\hline Video & $\begin{array}{l}\text { Video } \\
\text { Süresi }\end{array}$ & $\begin{array}{l}\text { Video } \\
\text { Kod } \\
\text { Sayısı } \\
\end{array}$ & Konum & $\begin{array}{c}\text { Kırsalda } \\
\text { Yaşama } \\
\text { Süresi }\end{array}$ & $\begin{array}{c}\text { Daha } \\
\text { Önceki } \\
\text { Meslek }\end{array}$ & Eğitim & $\begin{array}{c}\text { Daha } \\
\text { Önceki } \\
\text { İkamet }\end{array}$ & $\begin{array}{c}\text { Yürütülen Turizm } \\
\text { Faaliyeti }\end{array}$ \\
\hline Video-1 & $32.55^{\prime \prime}$ & 63 & $\begin{array}{l}\text { İzmir / } \\
\text { Menemen }\end{array}$ & 4 yil & Girişimci & $\begin{array}{l}\text { Yüksek } \\
\text { Lisans }\end{array}$ & İstanbul & $\begin{array}{l}\text { Kırsal Turizm } \\
\text { (Agro-Turizm) }\end{array}$ \\
\hline Video-2 & $11.18 "$ & 27 & $\begin{array}{c}\text { İzmir / } \\
\text { Karaburun }\end{array}$ & $1 \mathrm{y} 1 \mathrm{l}$ & Esnaf & Lisans & İstanbul & Kamp/Karavan \\
\hline Video-3 & 12.07" & 44 & $\begin{array}{c}\text { Rize / } \\
\text { Findıklı }\end{array}$ & - & Girişimci & - & İstanbul & $\begin{array}{l}\text { Kırsal Turizm } \\
\text { (Eko-Turizm) }\end{array}$ \\
\hline Video-4 & $30.01 "$ & 50 & İzmir / Urla & $10 \mathrm{y} 1 \mathrm{l}$ & $\begin{array}{c}\text { Kamu } \\
\text { Görevlisi }\end{array}$ & Lisans & İzmir & $\begin{array}{c}\text { Kırsal Turizm } \\
\text { (Çiftlik Turizmi) } \\
\end{array}$ \\
\hline Video-5 & $34.16 "$ & 38 & $\begin{array}{l}\text { Muğla / } \\
\text { Fethiye }\end{array}$ & $20 \mathrm{y} 1 \mathrm{l}$ & Turizmci & - & İstanbul & $\begin{array}{l}\text { Kirsal Turizm } \\
\text { (Agro-Turizm) }\end{array}$ \\
\hline Video-6 & $12.33^{\prime \prime}$ & 18 & $\begin{array}{l}\text { İzmir / } \\
\text { Siğacık } \\
\end{array}$ & 6 ay & Özel Sektör & Lisans & Ankara & $\begin{array}{c}\text { Pansiyon } \\
\text { İşletmeciliğ } \mathrm{I} \\
\end{array}$ \\
\hline
\end{tabular}




\section{Bulgular ve tartışma}

Yeni göç motivasyonları Tablo 2'de belirtilmiştir. Videolardan elde edilen bilgilere göre motivasyon unsurlarının itici ve çekici faktörler olarak ayrılmasına karar verilmiştir (Lee, 1966). Çekici faktörler, kültürel, sosyal, psikolojik, çevresel ve kişisel olmak üzere 5 alt kategoride incelenmiştir. İtici faktörler ise ekonomik, kültürel, sosyal, psikolojik ve çevresel olmak üzere 5 alt kategori altında incelenmiştir. Elde edilen bulgular doğrultusunda, yeni köylülerin geleneksel üretimden kopmadan, unutulan kültürü canlandırmaya çalışarak yaşamak istedikleri anlaşılmıştır. Kırsal hayattaki imece ve şehir hayatına göre samimi ve sosyal ilişkilerin bulunmasının çekici sosyal unsurlar olduğu anlaşılmıştır. Bu durumla ilgili aktarılan ifade şu şekildedir:

V4: “...insanlarla buradaki iletişimlerde çok içten ve candan, çok daha sicak oluyor. Bitkiyle de hayvanlarla da yani fark bana içsel olarak böyle geliyor..."

Göç edilen yerde doğanın insanlara sağladığı özgürlük, keyif hissi ve stresten uzak yaşama avantajları psikolojik faktörler arasındadır. Çekici psikolojik faktörlere örnek olarak şu ifadeler kullanılmıştır:

V3: “...Burada bunu fark edebiliyorsun. Yaşadiğını hissediyorsun. Kendine aitsin, kendin bir şekilde iradenle bir şeyleri yönlendirebiliyorsun ve gerçekten bir şeylere dokunabildiğini, bir şeylere yarayabildiğini, işlevli bir şeye fayda sağlayabildiğini biraz daha hissedebiliyorsun..."

\section{V4: “...burada çok daha büyük bir özgürlügü hissediyorsun.”}

Bununla birlikte, kırsal alanların getirdiği sessizlik, huzur, toprağa adım atmak, doğa manzarası gibi unsurlar da çevresel faktörler altında yer almıştır. Son olarak bireylerin ilgi ve istekleri doğrultusunda gruplandırılan kişisel faktörler altında göç edilen yere aşinalık, karavanlara yönelik ilgi, üreterek yaşama isteği ve sadeleşme olduğu görülmüştür.

İtici faktörler altında değerlendirilen ilk alt kategori ekonomik faktörlerdir. Buna göre, bireyler yoğun çalışma hayatından ve modern hayattaki emek sömürüsünden uzaklaşmak istemektedir. Kültürel faktörler altında ise kültür erozyonu, kitle turizmine ve popüler kültüre tepki olduğu tespit edilmiştir. Örneğin V5, daha önceki deneyiminde Marmaris'te turizmin gelişmesi ve toprakların değerlenmesi nedeniyle kırsal kesimin sosyal boyutta zarar gördüğünü aktarmıştır. Yola çıkış amacının Marmaris'te deneyimlediği kitle turizmine bir alternatif oluşturmak ve yerel halka katkı sağlamak olduğunu belirtmiştir.

V5: “...Köylü köyünde kalsın, yani hizmetkarlı yapmasın, o ev sahibi olsun misafirine hizmet etsin, misafir ev sahibi ilişskisini kuralım, gelen insanlar da buranın yerel yaşamını tatsın. Yemeğiyle, giyimiyle, mimarisiyle, ürünleriyle vs..."

Kalabalıktan ve mutsuz insanlardan kaçış sosyal faktörler altında incelenmiştir. Bireyleri şehir hayatından uzaklaşmaya iten psikolojik faktörlerin stres, aidiyet sorunu, modern yaşama doymuşluk, terör korkusu ve farklı bir yaşamı deneyimleme isteği olduğu anlaşılmıştır. V1, modern yaşamdaki aidiyet sorununu oluşturan alt kodlardan biri olan şehir yaşamının samimiyetsizliği, tutarsızlığı ve sahteliği üzerine şu ifadeleri kullanmıştır:

V1: “...Çevre eylemi düzenliyoruz, saatlerce insanlar orada ayakta bekliyor, sonra miting dă̆lliyor arkada çöp bırakıyoruz, yani orda konuştuklarımız bizim topluma anlattı̆̆ımız, kameralara söylediğimiz doğa koruma temizlik falan ama biz kirletiyoruz. Şimdi ben çocuklarıma da ayn tutarsızlıkla yaklaştığımı fark ettim bitaraftan ve işte o yaşamı değiş̧irmek için önemli bir ayrım oldu aslında bu tutarsizlık..." 
Tablo 2: Yeni köylü göç motivasyonları

\begin{tabular}{|c|c|c|c|}
\hline Tema & Kategori & $\begin{array}{c}\text { Alt Kategori } \\
\text { (Kodlama Sayısı) }\end{array}$ & Kod ve Alt Kodlar \\
\hline \multirow{10}{*}{ Motivasyon } & \multirow{5}{*}{$\begin{array}{c}\text { Çekici } \\
\text { Faktörler }\end{array}$} & $\begin{array}{c}\text { Kültürrel } \\
\text { Faktörler (8) }\end{array}$ & $\begin{array}{cc}\text { - Kültürden kopmamak } \\
\text { - Geleneksel bilgiye ulaşmak/geleneksel üretim } \\
-\quad \text { Taş ev yapımı } \\
-\quad \text { Ekmek yapımı } \\
\text { - } & \text { Peynir yapımı } \\
\text { - } & \text { Çimentosuz ev yapımı } \\
\text { - Unutulan/dışlanan kültürü canlandırmak }\end{array}$ \\
\hline & & Sosyal Faktörler (8) & $\begin{array}{l}\text { - Yerel halk arasındaki imece } \\
\text { - Geçmişsteki sosyal ilişkilere/yaşama özlem } \\
\text { - Samimi iletişim } \\
\end{array}$ \\
\hline & & Psikolojik Faktörler (7) & $\begin{array}{l}\text { - Yaşadığını hissetmek } \\
\text { - Doğaya çağırıldığını hissetmek } \\
\text { - Hayattan keyif almak } \\
\text { - Özgürlüğü hissetmek } \\
\text { - Stresten uzak yaşamak } \\
\end{array}$ \\
\hline & & Çevresel Faktörler (15) & $\begin{array}{l}\text { - Sessizlik } \\
\text { - Huzur } \\
\text { - Toprağa adım atmak } \\
\text { - Doğa manzarası } \\
\text { - Sakinlik/koşuşturmama } \\
\text { - Çocukların doğada büyümesi }\end{array}$ \\
\hline & & Kişisel Faktörler (8) & $\begin{array}{l}\text { - Göç edilen yere aşinalık } \\
\text { - Karavanlara yönelik ilgi } \\
\text { - Üreterek yaşama isteği } \\
\text { - Sadeleşme isteği } \\
\end{array}$ \\
\hline & \multirow{5}{*}{$\begin{array}{c}\text { İtici } \\
\text { Faktörler }\end{array}$} & Ekonomik Faktörler (5) & $\begin{array}{l}\text { - Modern yaşamdaki emek sömürüsünden kaçış } \\
\text { - Yoğun çalışma hayatından kaçış }\end{array}$ \\
\hline & & Kültürel Faktörler (4) & $\begin{array}{l}\text { - Kitle turizmine tepki } \\
\text { - Kırsal kesimin kültürel erozyona uğraması } \\
\text { - Popüler kültüre tepki }\end{array}$ \\
\hline & & Sosyal Faktörler (6) & $\begin{array}{l}\text { - Kalabalıktan kaçış } \\
\text { - Mutsuz insanlardan kaçış }\end{array}$ \\
\hline & & Psikolojik Faktörler (17) & $\begin{array}{ll}\text { - Stres } & \\
\text { - Modern yaşamdaki aidiyet sorunu } \\
\text { - } & \text { Kimlik kaybı } \\
\text { - } & \text { Şehir yaşamına ait olmadığını hissetme } \\
\text { - } & \text { Yaşadığını hissedememek } \\
\text { - } & \text { Şehir yaşamının insan doğasına aykırı olması } \\
\text { - } & \text { Şehir yaşamındaki samimiyetsizlik } \\
& \text { / tutarsılık / sahtelik } \\
\text { - } & \text { Şehir yaşamına uyum sağlayamamak } \\
\text { - } & \text { Hayatında yanlışlı/k/eksiklik hissetmek } \\
\text { - Modern yaşama doymuşluk } \\
\text { - Büyük şehirlerdeki terör korkusu } \\
\text { - Farklı bir yaşamı deneyimleme isteği } \\
\end{array}$ \\
\hline & & Çevresel Faktörler (7) & $\begin{array}{l}\text { - Fazla tüketime tepki } \\
\text { - Sürdürülebilir yaşamı destekleme isteği } \\
\text { - Betonlaşmadan kaçış } \\
\text { - Trafik sıkışılığı } \\
\text { - Doğayı hissedememek }\end{array}$ \\
\hline
\end{tabular}

Psikolojik itici faktörlere bir diğer örnek ise şu şekildedir:

V4: “...Arkadaşlarımızla birlikte mutlu bir yaşamdl. Ama bir şeyler eksikti, yani bir şeyleri tam böyle doğayı hissedemiyorduk. Niye böyle bir şey yapmayalım diye konuşmaya başladık..."

Son olarak çevresel faktörlerin fazla tüketime tepki, sürdürülebilir yaşamı destekleme isteği, betonlaşmadan kaçış, trafik sıkışıklığı ve bireylerin doğayı hissedememesi olduğu belirlenmiştir. Fazla tüketime tepki olarak V2 şu ifadeyi kullanmıştır: 
V2: “...Arkadaşlarım sürekli arabasını yeniliyordu. Arabası için tekrardan kredi alıyorlardı işte ev allyorlard $2+1$ yetmiyor bize $3+1$ alıyorlardı. 3+1 yetmiyor $4+1$ alalım sürekli böyle bir muhabbet böyle bir kredi silsilesi herkes bu sefer o krediyi ödeyebilmek için gece yarllarına kadar çalışmalar... şehirde olduğunuz zaman o silsileye dahil oluyorsunuz. Bende oldum belli bir süre. Ben ama ona dahil olmak istemediğimi anladım..."

Şekil 1: Yeni köylü motivasyonu kod bulutu

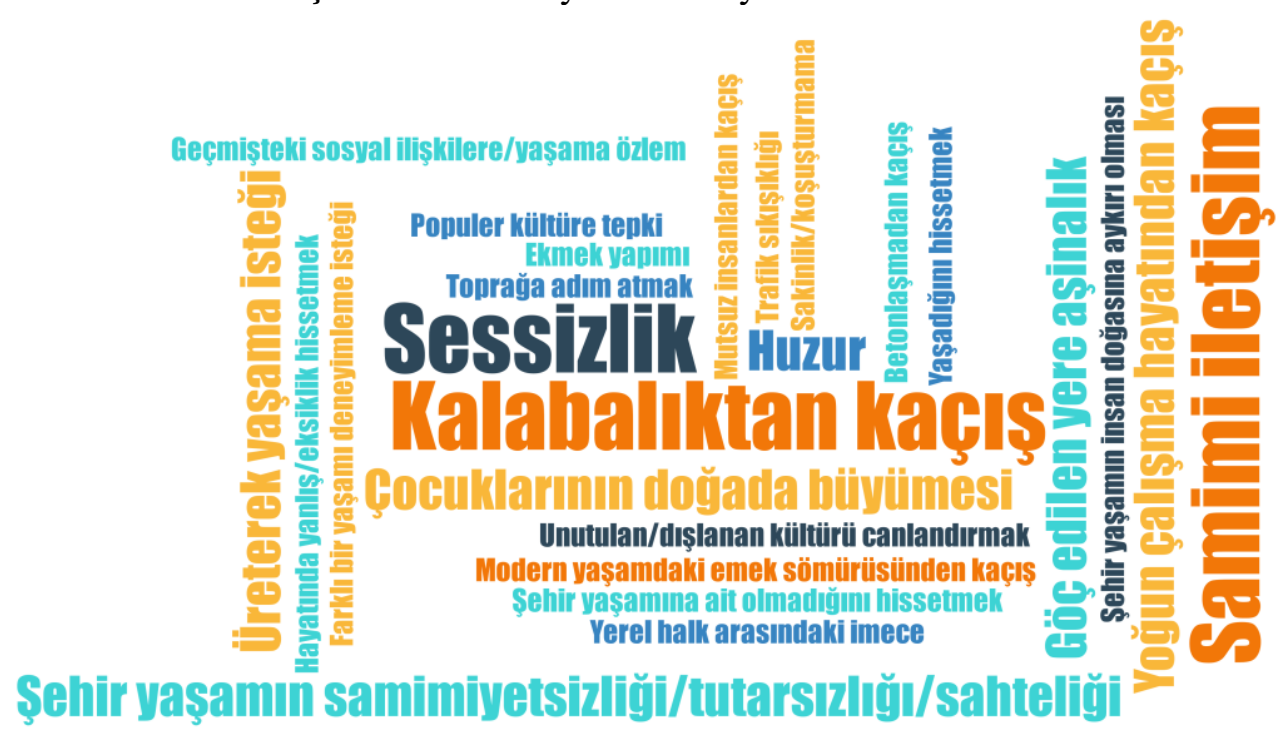

Yeni köylülerin motivasyonlarına ilişkin kod bulutu Şekil 1'de yer almaktadır. Şekilden de anlaşılabileceği gibi en yoğun vurgulanan kodlar kalabalıktan kaçış, sessizlik ve samimi iletişimdir. Yeni köylülerin karakteristik özellikleri Tablo 3'te sunulmuştur. Buna göre, yeni köylülerin doğaya önem veren, fazla tüketim karşıtı, insanı doğanın bir parçası olarak gören, modern yaşamın getirdiği alışkanlıklardan uzaklaşmak isteyen, kültüre bağlı kişiler olduğu söylenebilir. Yeni köylülerin kendilerini tanımlama biçimine örnek olarak şu ifadeler gösterilebilir:

V4: “... daha önceki köy yaşamları çok özendiğimiz bir yaşam şekli. Herkesin kendine ait bir bahçesi, hayvanı olup üretip bir şekilde tükettikleri bir yaşam şekliydi. Çok güzeldi. Şimdi bizler yeni köylüler olarak aynı bunu yaşatmak istiyoruz..."

Tablo 3: Yeni köylü karakteristik özellikleri

\begin{tabular}{|c|c|c|c|c|c|c|}
\hline Karakteristik Özellikler & V1 & V2 & V33 & V44 & V55 & $\overline{\mathrm{V6}}$ \\
\hline $\begin{array}{c}\text { Doğaya bağl1 } \\
\end{array}$ & & & & $\begin{array}{c}\checkmark \\
\end{array}$ & & \\
\hline "Doğada yaşamak isteyen & $\bar{\square}$ & $\begin{array}{c} \\
\end{array}$ & & & & \\
\hline Doğaya saygı duyan & & & & $\checkmark$ & $\checkmark$ & \\
\hline Doğaya zarar vermeyen & $\bar{~} \checkmark$ & & & & 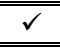 & \\
\hline 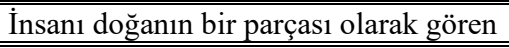 & & & & $\checkmark$ & & \\
\hline Fazla tüketim karşıtı & 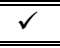 & $\begin{array}{l}\checkmark \\
\end{array}$ & & & $\checkmark$ & \\
\hline \multicolumn{7}{|l|}{ CCevreci aktivist } \\
\hline Organik tarımı destekleyen & & & $\checkmark$ & & $\checkmark$ & \\
\hline Yerli tohum kullanan & & & $\checkmark$ & & & \\
\hline "Kültürden kopmak istemeyen & $\checkmark \checkmark$ & & & & $\checkmark$ & \\
\hline Modern hayata adapte olamayan & $\checkmark$ & & & & & \\
\hline Haksızlığa tahammül edemeyen & & & $\checkmark$ & & & \\
\hline Aykırı kişilik & $\checkmark$ & & & & & \\
\hline Teknoloji kullanımına yatkın & $\checkmark$ & & & $\checkmark$ & & \\
\hline D1şa dönük & & & & & & $\bar{v}$ \\
\hline Geleceğe Yönelik Kaygılı & & $\checkmark$ & & & & \\
\hline
\end{tabular}

Yeni köylülerin göç sonrası kazanımları, yaşadığı zorluklar ve göç edecek kişilere yönelik tavsiyeleri Tablo 4'te sunulmuştur. Bu göre, yeni köylülerin doğaya, sosyal ilişkilere ve zindeliğe yönelik kazanımlar elde ettikleri, yeni yaşam biçiminin getirdiği çeşitli zorluklarla karşılaşıtıkları anlaşılmıştır. Son olarak, yaşam tarzını değiştirmek isteyen bireylerin doğaya uyum sağlamaları, bilinçli hareket 
etmeleri vurgulanmıştır. V3'ün betonlaşmaya neden olmamak ve şehirdeki alışkanlıkların kırsala taşınmamasına ilişkin ifadeleri aşağıda yer almaktadır.

V3: “... Bir şekilde bir cesaret edin, bir gayret edin ve buna doğru hayatınızı evirin. Ama tabi ki de benim diğer korkularımdan biri de gittiğiniz yerlere de o şehirdeki alışkanlıklarınızı ve yaşam biçiminizi veya konforunuzu veya betonumuzu veya tüketimimizi oraya da taşıdığımızda, zihnimizi de oraya taşılığımızda yine aynı zararı oraya veriyor olacağız..."

Tablo 4: Göç sonrası kazanımlar, zorluklar, tavsiyeler

\begin{tabular}{l||l||l}
\hline \multicolumn{1}{c||}{ Kazanımlar } & \multicolumn{1}{c}{ Zorluklar } & \multicolumn{1}{c}{ Tavsiyeler } \\
\hline \hline - Kontrol edilebilir bir hayat & - Yeni bir işin getirdiği stres & \\
- Doğayı hissetmek & - Sistemin dişına çıkmak & - Doğaya saygı duymak \\
- Öz gelişim sağlamak & - Yeni yaşam biçimine geçiş & - Betonlaşmaya neden olmamak \\
- Aileyle daha fazla vakit geçirebilmek & - Çocukların eğitimi & - Şehirdeki alışkanlıkları taşımamak \\
- Sosyal ilişkileri geliştirmek & - Uzun çalışma saatleri & - Adım adım ilerlemek \\
- Doğayı ve hayvanları sevmeyi & - Çocukların bakımı ve işlerin birlikte & - Cesur olmak \\
öğrenmek & yürütülmesi & - Fiziksel olarak güçlü olmak \\
- Sabırlı olmayı öğrenmek & - Doğada yaşamın zorlukları (Banyo- & - Bilinçli olarak gelmek \\
- Zindelik kazanmak & tuvalet-sıcak su, 1sinma) & - Gerçekten sevmek ve istemek \\
- Sadeleşmek & \\
\hline \hline
\end{tabular}

\section{Sonuç ve öneriler}

$\mathrm{Bu}$ çalışmada turizm girişimcisi olan yeni köylülerin motivasyonları, göç süreçleri ve girişimlerine dair deneyimlerinin ortaya çıkarılması amaçlanmıştır. Elde edilen bulgular ışığında yeni köylülerin doğayı kendi hayatlarının merkezine konumlandıran ve popüler kültürün dayattığ 1 fazla tüketim alışkanlıklarına karşı çıkan bireyler olduğu söylenebilir. Buna ek olarak yeni köylülerin geleneksel köy hayatında süregelen üretim ve yaşam biçimini devam ettirmek isteyen, modern yaşama uyum sağlayamayan, ama teknolojiyi de etkin kullanan kişiler oldukları ifade edilebilir. Bu açıdan değerlendirildiğinde, Başçı'nın (2019) yeni köylüler için nitelendirdiği melez yaşam biçiminin bu çalışmada da desteklendiği görülmektedir.

Yeni köylülerin, doğal yaşamı hayatlarının merkezine alan yaşam biçimini sürdürebilmek için turizm girişimciliğini bir araç olarak tercih ettikleri düşünülmektedir. Böylece, göç hareketinde bulunmalarına neden olan öncelikli motivasyonlarının turizm girişimciliği veya ekonomik fayda sağlamak değil, doğal ve sürdürülebilir bir yaşam biçimi olduğu ileri sürülebilir. Çalışmanın önemli bulgularından bir diğeri de çekici motivasyon faktörleri arasında çevresel faktörlerin, itici motivasyon faktörleri arasında da psikolojik faktörlerin öne ön plana çıkmasıdır. Çekici çevresel faktörler genellikle doğanın insanlara sunduğu avantajlar ile sakinlik ve dinginliğe vurgu yaparken, itici psikolojik faktörler bireyin modern yaşama uyumsuzluğuna ilişkin unsurlardan oluşmaktadır. Cao ve Yang (2019) tarafından yapılan araştırmada yeni köylüleri kırsal turizm girişimciliğine yönelten faktörlerin nostalji ve kendini gerçekleştirme gibi içsel ve doğal yaşamın çekicilikleri gibi dışsal unsurlardan oluştuğu tespit edilmiştir.

Kırsala göç süreci yeni köylü turizm girişimcileri tarafından doğal yaşama kaçış olarak nitelendirilmiştir. Bu kaçışın farklı sebepleri olmakla birlikte, temel olarak altta yatan sebeplerin; modern hayat içindeki kalabalık, betonlaşma, gereksiz tüketim nedeniyle daha fazla çalışma gibi sorunlar olduğu anlaşılmıştır. Nitekim benzer sebepler Eimermann (2015) ve Başçı (2019) tarafindan da vurgulanmıştır.

Özellikle Covid-19 gibi salgın hastalıklar nedeniyle şehirden kaçışların artacağı öngörülmektedir (Zoğal ve Emekli, 2020; Sürer, 2021). Bu doğrultuda yakın gelecekte yeni köylü turizm girişimciliği sayısının bu durumdan etkileneceği düşünülebilir. Ancak, şehirden kırsala göç ile birlikte, araştırma kapsamındaki yeni köylülerin de vurguladığı gibi, şehir yaşamının alışkanlıklarının kırsal alanlara taşınması ve bu göç hareketlerinin kitlesel bir duruma dönüşmesi ilerleyen sürede göz önünde bulundurulması gereken yeni tehditler oluşturabilir. 
Araştırmanın odak noktası, yeni köylü turizm girişimcilerinin yaşam tarzı değişikliği için çıktıkları bu yolculukta kendileri tarafından aktarılan deneyimlerinin kavramsallaştırılıp ilgili literatüre sunularak katkı sağlanmasıdır. Araştırmanın konusu ve kapsamı nedeniyle sınırlı sayıda veri kaynağı araştırmaya dâhil edilebilmiştir. Ulaşılabilen ve ilgili bulunan tüm kaynaklar incelenerek sadece içerik bakımından uygun bulunan ve ayrıntılı veri sağlayabilecek videolar değerlendirmeye alınmıştır. Bunun yanı sıra, bu konuda işbirliği yapılan ve etkileşim içerisinde bulunan yerel halkın görüşlerinin daha detaylı anlaşılmasının da önemli olduğu düşünülmektedir. Araştırmanın bu sinırlılığı kapsamında, gelecek çalışmalarda yerel halkın yeni köylülere bakış açısı değerlendirilebilir. Bununla birlikte yerel halkın bu göç hareketlerinden algıladıkları tehditler ve firsatlar incelenebilir ve araştırma sonucunda elde edilen motivasyon faktörleri daha büyük örneklem grupları üzerinde test edilebilir.

\section{Kaynakça}

Adıgüzel, Y. (2016). Göç sosyolojisi. Nobel Akademik Yayıncılık.

Akkaya, M. A. ve Gülçubuk, B. (2019). Kırsal gençliğin girişimcilikle imtihanı: Genç çiftçi desteği uygulaması üzerine bir inceleme. 4. International EMI Entrepreneurship and Social Sciences Congress Proceedings E-Book (1007-1015). İstanbul.

Aslan, S. (2019). Yaşam stili turizm girişimciliği üzerine kavramsal bir değerlendirme. International Social Sciences Studies Journal, 5(30), 617-625.

Ateljevic, I. ve Doorne, S. (2000). Staying within the fence: Lifestyle entrepreneurship in tourism. Journal of Sustainable Tourism, 8(5), 378-392.

Başçı, E. (2019). Köylüleşen gönüllü sadeler üzerine etnografik bir araştırma. Sosyoloji Notları, 3(2), $2-20$.

Benson, M. ve O’Reilly, K. (2009a). Lifestyle migration: Expacxtations, aspirations and experiences. Ashgate Publishing.

Benson, M. ve O'Reilly, K. (2009b). Migration and the search for a better way of life: A critical exploration of lifestyle migration. The Sociological Review, 57(4), 608-625.

Bérard, L., Marchenay, P. ve Casabianca, F. (2010). Bilgi ve beceriler, yöreler, ürünler: Biyolojik ve kültürel özvarlık. S. Tozanlı (Çev.). Akdeniz IIIBF Dergisi, 10(19), 148-160.

Bostan, H. (2017). Türkiye'de iç göçlerin toplumsal yapıda neden olduğu değişimler, meydana getirdiği sorunlar ve çözüm önerileri. Coğrafya Dergisi, 35, 1-16.

Braun, V. ve Clarke, V. (2006). Using thematic analysis in psychology. Qualitative research in psychology, 3(2), 77-101.

Bülbül, S. ve Köse, A. (2010). Türkiye'de bölgelerarası iç göç hareketlerinin çok boyutlu ölçekleme yöntemi ile incelenmesi. İstanbul Üniversitesi İsletme Fakültesi Dergisi, 39(1), 75-94.

Cao, X. ve Yang, Y. (2019). Rural tourism "new villagers" makers under the guidance of "homesickness" rural tourism entrepreneurship motivation model based on grounded theory. 5th International Conference on Economics, Management and Humanities Science, Bangkok, Thailand.

Chacko, E. (2007), From brain drain to brain gain: Reverse migration to Bangalore and Hyderabad, India's globalizing hightech cities. Geojournal, 68, 131-140.

Çağlayan, S. (2006). Göç kuramları, göç ve göçmen ilişkisi. Muğla Üniversitesi Sosyal Bilimler Enstitüsü Dergisi, (17), 67-91.

Dollinger, M. J. (2008). Entrepreneurship: Strategies and resources (4th ed.). Marsh Publications.

Eimermann, M. (2015). Lifestyle migration to the North: Dutch families and the decision to move to rural Sweden. Population, Space and Place, 21, 68-85.

Ekici, S. ve Tuncel, G. (2015). Göç ve insan. Birey ve Toplum Sosyal Bilimler Dergisi, 5(1), 9-22.

Ela Özcan, E. D. (2017). Çağdaş göç teorileri üzerine bir değerlendirme. İş ve Hayat, 2(4), 183-215.

Erlandson, D. A., Harris, E. L., Skipper, B. L. ve Allen, S. D. (1993). Doing naturalistic inquiry: A guide to methods. Sage.

Gümüş, N., İlhan, A. ve Gülersoy, A. E. (2013). Bir tersine göç örneği: Köprücük Köyü (VartoMuș). Electronic Turkish Studies, 8(6), 233-261.

Güreşci, E. (2010). Türkiye'de kentten köye göç olgusu. Doğuş Üniversitesi Dergisi, 11(1), 77-86.

Güreşci, E. ve Yurttaş, Z. (2008), Kırsal göçün nedenleri ve tarıma etkileri üzerine bir araştırma: Erzurum ili İspir İlçesi Kırık Bucağı örneği. Tarım Ekonomisi Dergisi, 14(2), 47-54.

Güvenç, B. (1999). İnsan ve kültür. Remzi Kitabevi 
İçduygu, A., Sirkeci, İ. ve Aydıngün, İ. (1998). Türkiye'de içgöç ve içgöçün işçi hareketine etkisi. A. İçduygu, İ. Sirkeci ve İ. Aydıngün (der.) Türkiye'de İçgöç: Türkiye'de İçgöç, Sorunsal Alanları ve Araştırma Yöntemleri Konferansı 6-8 Haziran 1997 (207-244). Tarih Vakfi Yurt Yayınları.

İçli, G. (1998, 15-16 Ekim). Denizli iline göç eden ailelerin eğitime bakış açıları. 4. Ulusal Sınıf Öğretmenliği Sempozyumu, Denizli.

İslamoğlu, E., Yıldırımalp, S. ve Benli, A. (2014). Türkiye'de tersine göç ve tersine göçü teşvik eden uygulamalar: İstanbul ili örneği. Sakarya İktisat Dergisi, 3(1), 68-93.

İslamoğlu, E., Yıldırımalp, S. ve Man, F. (2017). Türkiye'de tersine göçe neden olan faktörler üzerine bir araştırma. O. Köse (Ed.), Geçmişten günümüze göç III içinde (ss. 1849- 1857) Canik Belediyesi Kültür Yayınları.

Lee, E. S. (1966). A theory of migration. Demography, 3(1), 47-57.

Lordkipanidze, M., Brezet, H. ve Backman, M. (2005). The entrepreneurship factor in sustainable tourism development. Journal of Cleaner Production, 13, 787-798.

Merriam, S. B. (2013). Nitel araştırma: Desen ve uygulama için bir rehber. (S. Turan, Çev. Ed.). Nobel. (Orijinali 2009'da yayımlanmıştır).

Özdemir, Ş. (2020). Tüketim karşıtı yeni yaşam biçimi köye dönüşün medyada sunumu: Yeni köylüler örneği. Erciyes Illetişim Dergisi, 7(2), 833-852.

Ravenstein, E. G. (1885). The laws of migration. Journal of the Statistical Society of London, 48(2), 167-235.

Savgın, C. ve Zengin, B. (2018). Türkiye'de çiftlik turizmine yönelik kavramsal bir model önerisi. The Journal of Academic Social Sciences, 6(86), 239-258.

Sayın, Y., Usanmaz, A. ve Aslangiri, F. (2016). Uluslararası göç olgusu ve yol açtı̆̆1 etkiler: Suriye göçü örneği. KMÜ Sosyal ve Ekonomik Araştırmalar Dergisi, 18(31), 1-13.

Schumpeter, J. A. (2000). Entrepreneurship as innovation. University of Illinois at UrbanaChampaign's Academy for Entrepreneurial Leadership Historical Research Reference in Entrepreneurship. $\quad 27 \quad$ Ağustos $2021 \quad$ tarihinde https://papers.ssrn.com/sol3/papers.cfm?abstract_id=1512266 adresinden erişildi.

Sun, X. ve Xu, H. (2017). Lifestyle tourism entrepreneurs' mobility motivations: A case study on Dali and Lijiang, China. Tourism Management Perspectives, 24, 64-71.

Südaş, İ. ve Mutluer, M. (2010). Daha iyi bir hayata doğru: "Yaşam biçimi göçü". Ege Coğrafya Dergisi, 19(1), 31-47.

Sürer, A.G. (2021). Covid-19 sürecinde kentten kırsala dönüş. Kapadokya Coğrafya Dergisi, 1(3), 112.

Swan, C.D. ve Morgan, D. (2016). Who wants to be an eco-entrepreneur? Identifying entrepreneurial types and practices in ecotourism businesses. The International Journal of Entrepreneurship and Innovation, 17(2), 120-132.

Şen, M. (2014). Türkiye'de iç göçlerin neden ve sonuç kapsamında incelenmesi. Çalışma ve Toplum, 40(1), 231-256.

TUIK. (2020). Yillara ve cinsiyete göre il/ilçe merkezleri ve belde/köyler nüfusu, 1927-2019. 27.12.2020 tarihinde https://turkstatweb.tuik.gov.tr/PreIstatistikTablo.do?istab_id=1587 adresinden erişildi.

Wilson, L. A. (2007). The family farm business? Insights into family, business and ownership dimensions of open-farms. Leisure Studies, 26(3), 357-374.

Yıldırım, A. ve Şimşek, H. (2016). Sosyal bilimlerde nitel araştırma yöntemleri. (10. genişletişmiş baskı), Seçkin Yayıncılık.

Yılmaz, A. (2014). Uluslararası göç: Çeşitleri, nedenleri ve etkileri. Turkish Studies, 9(2), 1685-1704.

Zoğal, V. ve Emekli, G. (2020). The changing meanings of second homes during Covid-19 Pandemic in Turkey. International Journal of Geography and Geography Education (IGGE), 42, 168-181. 


\section{Etik kurul onayı}

Katılımcılardan veri toplanmasını gerektirmemesi sebebi ile bu araştırma etik kurul izni gerektirmeyen çalışmalar arasında yer almaktadır.

Araştırmacıların katkı oranı beyanı

Yazarlar çalışmaya eşit oranda katkı sağlamıştır.

Çıkar çatışması beyanı

Bu çalışmada herhangi bir potansiyel çıkar çatışması bulunmamaktadır. 